\title{
Microbes and Health
}

ISSN: 2226-0 153 (Print) 2305-3542 (Online)

http://journal.bsvmph.org/

Microbes and Health, January 2015, 4(1): 19-24

DOI: $10.3329 / \mathrm{mh} . v 4 \mathrm{i} 1.23089$

\section{ORIGINAL RESEARCH ARTICLE}

\section{Molecular Cloning cysK Gene from Escherichia coli Genome, Transferring in the Intestinal Sulfate- Reducing Bacteria and the Expression Analysis of $\boldsymbol{O}$-acetylserine(thiol)lyase}

\author{
Ivan V. Kushkevych ${ }^{1,2 *}$ \\ ${ }^{1}$ Institute of Animal Biology of NAAS of Ukraine, V.Stus St 38, Lviv 79034, Ukraine. \\ ${ }^{2}$ University of Veterinary and Pharmaceutical Sciences Brno, Palackeho 1/3, CZ-61242 Brno, Czech Republic.
}

*Corresponding author's email: ivan.kushkevych@gmail.com

\begin{abstract}
Sulfate-reducing bacteria produce hydrogen sulfide which is toxic and carcinogenic for intestinal epithelial cells and can cause the development of the inflammatory bowel disease and ulcerative colitis in the humans and animals. Enzyme $O$-acetylserine(thiol)lyase, localized in Escherichia coli genome, use sulfide as substrate in the cysteine synthesis pathway. In this paper, the molecular cloning cys $K$ gene from $E$. coli, its genetic transferring in the intestinal sulfate-reducing bacterium Desulfovibrio piger Vib-7 and the expression analysis of the enzyme was studied. Cysteine synthesis from hydrogen sulfide as substrate in the D. piger Vib-7 strain at the first time was demonstrated and characterized. The bacterial growth, sulfate and lactate consumption, accumulation of sulfide, acetate and cysteine synthesis in both $D$. piger Vib-7 wild-type and mutant-type were tested. The mutant-strain consumed much faster sulfate and lactate producing cysteine in the cultivation medium. The expression of the cys $K$ gene in the mutant-type was studied by the formation of the final reaction product (cysteine) and the activity of $O$ acetylserine(thiol)lyase enzyme. Cysteine level was directly proportional to consumption of sulfate in the mutant-type and accumulation of sulfide in the wild-type. The D. piger Vib-7 mutant-type completely used sulfate the $48^{\text {th }}$ hour of cultivation, thereafter additional sulfite and sulfide doses from the medium were also consumed and converted to cysteine. The obtained genetically constructed mutant strain bacterium $D$. piger Vib-7 for therapeutic strategy could be applied as a probiotic substance for subjects with inflammatory bowel disease and ulcerative colitis. This strain can compete with other intestinal sulfate-reducing bacteria, actively growth consuming sulfate and lactate much faster, and converting the toxic sulfide to untoxic cysteine in the gut.
\end{abstract}

Key Words: Sulfate-Reducing Bacteria, Hydrogen Sulfide, Toxicity, Ulcerative Colitis, Cysteine

(C) 2015 Microbes and Health. All rights reserved

\section{Introduction}

Sulfate-reducing bacteria Desulfovibrio genera belong to the intestinal microbiota of humans and animals (Gibson et al., 1991; Barton and Hamilton, 2010). They consume sulfate as an electron acceptor, and the organic compounds as an electron donor and carbon source in the process of dissimilatory sulfate reduction (Kushkevych, 2012a,b). The lactate is the most common substrate used by the species belonging to the intestinal sulfate-reducing bacteria (Gibson et al., 1991; Kushkevych, 2012a). The species of Desulfovibrio genera oxidize lactate incompletely to acetate (Barton and Hamilton, 2010). Lactate oxidation to acetate occurs together with the concurrent reduction of sulfate to hydrogen sulfide (Rowan et al., 2009; Kushkevych, 2012a).

Sulfide and acetate, the final products of sulfate-reducing bacteria Desulfovibrio genus, play an important etiologic role in the inflammatory bowel disease and ulcerative colitis (Cummings et al., 2003; Kushkevych, 2012b; Levine et al., 1998; Loubinoux et al., 2000, 2002). The intensive growth of the sulfate-reducing bacteria and their sulfate reduction in the human and animal colon contributes to accumulation of these final products in high concentration (Loubinoux et al., 2002; Pitcher and Cummings, 1996; Rowan et al., 2009; Ohge et al., 2003). These compounds are the highly toxic, mutagenic and carcinogenic to the intestinal epithelial cells, and can cause damage to the integrity of the epithelial barrier cells and inflammation of the colon epithelium (Roediger et al., 1993a,b; Rowan et al., 2009). Hydrogen sulfide can also cause inhibition of cytochrome oxidase, colonocytes oxidation of butyrate, destruction of the cells, development of ulcers and inflammation with a subsequent development of colon cancer (Roediger et al., 1986; Pitcher and
Cummings, 1996; Chapman et al., 1994; Cummings et al., 2003). Thus, the increased number of the sulfate-reducing bacteria and intensive of dissimilatory sulfate reduction in the gut can cause inflammatory bowel diseases of humans and animals (Kushkevych, 2012b).

The species of Desulfovibrio genera most commonly were found in the intestines of humans and animals during various inflammatory bowel diseases (Cummings et al., 2003; Pitcher and Cummings, 1996; Gibson et al., 1991; Kushkevych, 2012b). These bacteria were also often found in persons with rheumatic diseases, and with ankylosing spondylitis, etc. (Barton and Hamilton, 2010). The species of Desulfovibrio genus also caused the bloody diarrhea, weight loss, anorexia, epithelial hyperplasia, abscesses and inflammatory infiltrates in animals and humans (Cummings et al., 2003; Loubinoux et al., 2000, 2002; Kushkevych, 2012a). The injection of these bacteria in hamster intestine caused infection is clinically similar to human colitis (Low et al., 2013). The increased number of sulfate-reducing microorganisms was in feces from people with ulcerative colitis (Pitcher and Cummings, 1996). There was also assumption that sulfate-reducing bacteria can cause some forms of cancer of the rectum through the formation of hydrogen sulfide (Cummings et al., 2003).

The enzyme of $O$-acetylserine(thiol)lyase (OASTL, EC 4.2.99.8) catalyzes cysteine biosynthesis from hydrogen sulfide in Escherichia coli (Boronat et al., 1984). The enzyme (previously known as $O$ acetylserine sulphydrylase A, OASS-A), isolated from Salmonella typhimurium by Becker et al. (1969), is a protein of $M_{\mathrm{r}} 68000$ and composed of two identical subunits of $M_{\mathrm{r}} 34000$. The subunit of OASTL is the product of the cysK gene (Becker et al., 1969). Addition 
of cysteine to cultures of $S$. typhimurium and E. coli represses the synthesis of OASTL and the expression of the cysteine biosynthetic enzymes requires a positive regulator that is specified by the $c y s B^{+}$ gene (Jones-Mortimer, 1968). The cysK gene maps at about $52 \mathrm{~min}$ on the genomes of E. coli (Fimmel and Loughlin, 1977; Wiater and Hulanicka, 1979; Boronat et al., 1984).

In literature, there are a lot of data on the role of the intestinal microorganisms in the development of inflammatory bowel diseases and ulcerative colitis in animals and humans (Cummings et al., 2003; Pitcher and Cummings, 1996; Gibson et al., 1991; Levine et al., 1998; Loubinoux et al., 2000, 2002; Roediger et al., 1993a,b; Rowan et al., 2009). However, the solution to this important problem has not been well-characterized. The treatment of these diseases is often to apply the toxic antibiotics and various antimicrobial agents which are inhibiting not only sulfate-reducing bacteria but also other intestinal microorganisms. As far as it is aware, these conditions often cause the intestinal dysbiosis.

The aim of this work was to clone the gene of $O$ acetylserine(thiol)lyase from E. coli $\mathrm{K}-12$ and transfer of this gene to the intestinal sulfate-reducing bacteria Desulfovibrio piger Vib-7 cells constructing the mutant strain which could be to synthesize cysteine from sulfide as well as to carry out the expression analysis of the enzyme.

\section{Materials and Methods}

The object of the study was the sulfate-reducing bacteria of the Desulfovibrio piger strain Vib-7 isolated from the human large intestine (Kushkevych, 2013) and identified by the sequence analysis of the 16S rRNA gene (Kushkevych et al., 2014). The strain has been kept in the collection of microorganisms at the Laboratory of Biotechnology, Faculty of Pharmacy, University of Veterinary and Pharmaceutical Sciences Brno (Czech Republic).

\section{Cultivation of the sulfate-reducing bacteria}

The bacteria were grown in a nutrition-modified Kravtsov-Sorokin's liquid medium (Kushkevych, 2013) following composition (g/l): $\mathrm{Na}_{2} \mathrm{SO}_{4}-0.5 ; \mathrm{KH}_{2} \mathrm{PO}_{4}-0.3 ; \mathrm{K}_{2} \mathrm{HPO}_{4}-0.5 ;\left(\mathrm{NH}_{4}\right)_{2} \mathrm{SO}_{4}-0.2 ; \mathrm{NH}_{4} \mathrm{Cl}-$ 1.0; $\mathrm{CaCl}_{2} \times 6 \mathrm{H}_{2} \mathrm{O}-0.06 ; \mathrm{MgSO}_{4} \times 7 \mathrm{H}_{2} \mathrm{O}-0.1 ; \mathrm{C}_{3} \mathrm{H}_{5} \mathrm{O}_{3} \mathrm{Na}-2.0$; yeast extract - 1.0; $\mathrm{FeSO}_{4} \times 7 \mathrm{H}_{2} \mathrm{O}-0.004$; sodium citrate $\times 2 \mathrm{H}_{2} \mathrm{O}-0.3$. Before bacteria seeding in the medium, $0.05 \mathrm{ml} / 1$ of sterile solution of $\mathrm{Na}_{2} \mathrm{~S} \times 9 \mathrm{H}_{2} \mathrm{O}(1 \%)$ to initiate bacterial growth was added. A sterile $10 \mathrm{~N}$ solution of $\mathrm{NaOH}(0.9 \mathrm{ml} / \mathrm{l})$ in the medium (for the final $\mathrm{pH} 7.2)$ was used. The medium was heated in boiling water for $30 \mathrm{~min}$ in order to obtain an oxygen-free medium, and then cooled to $+30^{\circ} \mathrm{C}$. The bacteria were grown for 72 hours at $+37^{\circ} \mathrm{C}$ under anaerobic conditions. The tubes (volume $1.5 \mathrm{ml}$ ) were brim-filled with medium containing bacteria and closed to provide anaerobic conditions.

\section{Genetic procedure}

CysK gene was cloned from $E$. coli $\mathrm{K}-12$ and transferred into the $D$. piger Vib-7. The presence of the CysK gene in D. piger Vib-7 was verified using the BLAST algorithm in the GenBank database. According to the obtained gene sequence, the specific primers for the polymerase chain reaction were used. Genomic DNA from E. coli K12 was obtained from single bacterial colony, which was triturated in sterile water and heated to $+90^{\circ} \mathrm{C}$ for five minutes. Free DNA was centrifuged at $14,600 \mathrm{~g}$ for three minutes to separate and remove the cells debris. DNA remaining in the supernatant was used to amplify the CysK gene using gradient PCR. HotStar Master Mix Taq polymerase (QIAGEN), UDG-glycosylase (New England Biolabs) and primers CysK-R and CysK-F (Generi-Biotech) for cloning were used:

Forward Primer: (cgaggcagatct tag); cysK-F: cgaggcagatctAATTAATTGGGAATACGC Reverse Primer: (cgaggcagatctctcgag tag); cysK-R: cgaggcagatctctcgagGCTCAGCACCATATGCGC.
The gradient PCR reaction was initially heated to $+37^{\circ} \mathrm{C}$ for 2 minutes, then at $+95^{\circ} \mathrm{C}$ for 10 minutes, followed by 35 cycles of $+95^{\circ} \mathrm{C}$ for 15 seconds, the temperature gradient from $+45^{\circ} \mathrm{C}$ to $+69^{\circ} \mathrm{C}$ for 30 seconds, and $+72^{\circ} \mathrm{C}$ for 30 seconds, followed by a step for 7 minutes at $+72^{\circ} \mathrm{C}$ and the final cooling to $+10^{\circ} \mathrm{C}$.

The PCR products were analyzed by electrophoresis continued for 45 minutes at $10 \mathrm{~V} / \mathrm{cm}$ to $2 \%$ electrophoresis gel in buffer $0.5 \mathrm{x}$ of TBE, the staining was performed using a fluorescent substance GelRed (Labmark). Before electrophoresis, the PCR products were mixed with the GLB buffer ( $5 \mu \mathrm{l}$ of buffer to $25 \mu \mathrm{l} \mathrm{PCR}$ ) in an amount of $5 \mu \mathrm{l}$ applied to an electrophoretic gel. As the size standard, $100 \mathrm{bp}$ ladder (Malamité) was used.

Specific amplicons of $600 \mathrm{bp}$ were cut out from the gel and purified commercial MinElute Gel Extraction Kit (QIAGEN) according to manufacturer's instructions. The ligation mixture contained $4 \mu \mathrm{l}$ of the PCR product (the concentration was estimated at $1.75 \mathrm{ng} / \mu \mathrm{l}$ ), $1 \mu \mathrm{l}$ of vector pSTVib-7 AccepTor ${ }^{\mathrm{TM}}$ (concentration $50 \mathrm{ng} / \mu \mathrm{l}$ ) and $5 \mu \mathrm{l}$ Clonable $^{\mathrm{TM}} 2 \mathrm{x}$ Ligation Premix (Novagen). Ligation was carried out for 2 hours at $+14^{\circ} \mathrm{C}$.

The ligation products were transformed into D. piger Vib-7 using AccepTor ${ }^{\mathrm{TM}}$ Vector Kit (Novagen). Before that, the bacterial cells were thawed on ice and $1 \mu \mathrm{l}$ of the ligation mixture was added. After incubation on ice lasting 5 minutes, the mixture was immersed in a water bath at $+42^{\circ} \mathrm{C}$ for exactly 30 seconds, and moved back to ice. To the mixture, $250 \mu \mathrm{l}$ of regeneration medium was added and left horizontally shaken at $220 \mathrm{rpm}$ and $+37^{\circ} \mathrm{C}$ for 30 minutes. In total 50 $\mu \mathrm{l}$ of the transformed cells were smeared on a bacteriological stick and passed in warm $\left(+30^{\circ} \mathrm{C}\right)$ nutrition-modified Kravtsov-Sorokin's agar medium (Kushkevych, 2013) containing IPTG ( $\mathrm{c}=2 \mu \mathrm{l} / \mathrm{ml})$, X-GAL $(\mathrm{c}=4 \mu \mathrm{l} / \mathrm{ml})$, kanamycin $(\mathrm{c}=1 \mu \mathrm{l} / \mathrm{ml})$ and tetracycline $(\mathrm{c}=15 \mu \mathrm{l} / \mathrm{ml})$. After 48 hours of cultivation at $+37^{\circ} \mathrm{C}$, the grown colonies in thickness of the medium on the Petri dishes were observed and the selection of transformed cells by the below mentioned components was carried out.

Plasmid DNA from the selected transformants D. piger Vib-7 (pSTVib-7-CysK) was isolated using QIAprep Spin Miniprep Kit (QIAGEN). The presence of the inserted CysK gene in the plasmid was confirmed by polymerase chain reaction using Maxima $^{\mathrm{TM}}$ Probe qPCR Master Mix 2X, „FERMENTAS” and universal primers M13R and M13F20. The reaction was according to the following scheme: 2 minutes at $+37^{\circ} \mathrm{C}, 15$ minutes at $+95^{\circ} \mathrm{C}, 35$ cycles of 10 seconds at $+95^{\circ} \mathrm{C}, 20$ seconds at $+50^{\circ} \mathrm{C}$ and 30 seconds at $+72^{\circ} \mathrm{C}, 5$ minutes at $+72^{\circ} \mathrm{C}$ and final cooling to $+10^{\circ} \mathrm{C}$. The PCR products were analyzed by electrophoresis in a $1.5 \%$ gel. The sequence of the cloned gene plasmids CysK was confirmed by sequencing.

\section{Isolation of CysK mutants}

The CysK mutants were isolated by spreading $0.2 \mathrm{ml}$ of overnight culture on the Kravtsov-Sorokin's agar medium containing IPTG $(\mathrm{c}=0.5 \mu \mathrm{l} / \mathrm{ml})$ and X-GAL $(\mathrm{c}=2 \mu \mathrm{l} / \mathrm{ml})$ and on the $10 \mathrm{mM}$ of triazole Kravtsov-Sorokin's agar plates or on the plates containing $4.5 \mathrm{mg} / \mathrm{ml}$ of azaserine and $0.1 \mathrm{mM}$ of L-cysteine. Mutants arised spontaneously; all colonies which appeared after a few days on plates containing inhibitors were resistant to the inhibitor used. In same case, triazole plates were supplemented with L-methionine to a final concentration of $0.1 \mathrm{mM}$. The method was applied to the strains of D. piger Vib-7 (pSTVib-7-CysK) (test, mutant strain) and D. piger Vib-7 (pSTVib-7) (control, wild-type).

\section{Assay of $O$-acetylserine(thiol)lyase}

Strains were grown in the Kravtsov-Sorokin's media supplemented with $10 \mathrm{mM}$ of sodium lactate and ampicillin $(100 \mathrm{mg} / \mathrm{ml})$ with or without cystine $(100 \mathrm{mg} / \mathrm{ml})$ at $+37^{\circ} \mathrm{C}$ overnight. Samples $(20 \mathrm{mg}$ dry mass $/ \mathrm{ml}$ ) were sonicated in an ultrasonic bath (Megason) for $10 \mathrm{~min}$, centrifuged and the supernatants assayed for the production of cystcine 
from O-acctylscrine and hydrogen sulfide according to the method of Fimmel and Loughlin (1977). Protein concentration in the cell-free extracts was determined by the Lowry method (Lowry et al., 1951).

\section{Assay of cysteine production in D. piger Vib-7 mutant-type}

A cysteine production in the Kravtsov-Sorokin's liquid medium by the D. piger Vib-7 mutant-type was studied. The mutant-type was also cultivated in the medium with sulfate+sulfite or sulfate+sulfide as a sulfur source, $3+3 \mathrm{mM}$ of sodium sulfate+sulfite or $3+3 \mathrm{mM}$ of sodium sulfate+sulfide, respectively. The culture was grown at $37^{\circ} \mathrm{C}$ for $84 \mathrm{~h}$, and the amount of cysteine accumulated during this time in the medium was quantified. The quantification of cysteine was performed by the method described by Gaitonde (1967). The experiment was performed in five-plicate, and averages and standard deviations of the accumulated cysteine amounts were calculated.

\section{Assay of bacterial biomass}

Optical density of sulfate-reducing bacteria D. piger Vib-7 in the liquid medium (without Mohr's salt) was determined by the dilute suspension of the bacterial cells using the photometric method (Sutton, 2011). The biomass of the cells was calculated by the formula:

$$
C=\frac{E \times n}{K},
$$

where $C$ - bacterial biomass ( $\mathrm{mg}$ cells $/ \mathrm{ml}$ of medium); $E$ - extinction at $\lambda \mathrm{nm}(\lambda=340 \mathrm{~nm}) ; n$ - dilution factor, times; $K$ - coefficient of conversion, obtained gravimetrically $(K=0.19)$.

\section{Assay of sulfate, lactate sulfide and acetate in cultivation medium}

The sulfate ion concentration in the medium was determined by the turbidimetric method after it had been precipitated by barium chloride. To stabilize the suspension, glycerol was used (Kolmert et al., 2000). Lactate concentration was measured through the dehydrogenation reaction using Lactate Assay Kit (Sigma-Aldrich, Catalog Number MAK064). Sulfide concentration in the culture medium was assayed by the spectrophotometric method as was described in paper (Cline 1969). Accumulation of acetate ions in process of bacterial growth in the medium was determined using Acetate Assay Kit (Colorimetric, Catalog Number KA3764).

\section{Statistical analysis}

The statistical calculations of the results were carried out using the software MS Office and Origin computer programs. The research results were treated by the methods of variation statistics using Student $t$-test. The equation of the straight line that the best approximates the experimental data was calculated by the method of least squares. The absolute value of the correlation coefficient $r$ was from 0.90 to 0.98 . The statistical significance of the calculated parameters of line was tested by the Fisher's F-test. The accurate approximation was when $\mathrm{P} \leq 0.05$ (Bailey, 1995).

\section{Results and Discussion}

Physiological and biochemical properties of the strain of D. piger Vib7 mutant-type were studied (Fig. 1, 2). The results of our studied shown, the accumulated biomass of the mutant-type and wild-type in Kravtsov-Sorokin's liquid medium was quite different. However, the stationary growth phase for both bacterial types at the $60^{\text {th }}$ hour was began; at this time, the accumulated biomass of the D. piger Vib-7 mutant-type was $36 \%$ higher compared to the wild-type (Fig. 1A). These data were consistent to the studies of dynamics of sulfate and lactate consumption as well as accumulation of sulfide/cysteine and acetate (Fig. 1B). In this case, the level of sulfate and lactate in the medium at the $60^{\text {th }}$ hour was minimal values. It should also be noted that the mutant-type D. piger Vib-7 consumed these substrates much faster than the wild-type. The level of the accumulated sulfide $(3.11 \pm$
$0.28 \mathrm{mM})$ in the wild-type and cysteine $(3.26 \pm 0.31 \mathrm{mM})$ in the mutant-type was directly proportional to consumption of sulfate at the $60^{\text {th }}$ hour of cultivation. Similar pattern was observed in the case of lactate consumption and acetate accumulation for both bacterial types . However, the values of consumption and accumulation of these compounds for the mutant- and wild-type were more similar (15.21 \pm 1.49 and $15.63 \pm 1.54 \mathrm{mM}$, respectively) (Fig. 1C).

As shown in fig $1 B, D$. piger Vib-7 mutant-type completely consumed sulfate at the $48^{\text {th }}$ hour of cultivation. Final products of the dissimilatory sulfate reduction in the sulfate-reducing bacteria are sulfite and sulfide (Kushkevych, 2012a). Therefore, the following our task was to study of the potential consummation of sulfite and sulfide for synthesis of cysteine by D. piger Vib-7 mutant-type (Fig. 2A). As results shown, the mutant-type consumed of both these compounds accumulating cysteine in the medium. The highest cysteine accumulation $\left(5.38 \pm 0.52 \mathrm{mM}\right.$ at the $84^{\text {th }}$ hour of cultivation) was observed in the medium with additional sulfide. However, D. piger Vib-7 mutant-type after the $84^{\text {th }}$ hour consumed sulfide incompletely. In this case, sulfite consumption was completely. Under these conditions, the level of accumulated cysteine was lower $(4.32 \pm 0.41$ $\mathrm{mM}$ ) than in case with sulfide. The consumption of sulfite and sulfide in the mutant-type was directly proportional to cysteine accumulation. It should be also noted that the level of cysteine from $48^{\text {th }}$ to $84^{\text {th }}$ hour was almost unchanged in the control medium with sulfate. It confirmed that sulfate at the $48^{\text {th }}$ hour was completely consumed. These data were consistent to enzyme activity of $O$-acetylserine (thiol) lyase under the effect of sulfate, sulfite and sulfide during bacterial growth in the cultivation medium (Fig. 2B). The highest enzyme activity $\left(62.12 \pm 6.23,74.31 \pm 7.34,97.56 \pm 8.97 \mathrm{U} \times \mathrm{mg}^{-1}\right.$ protein) for sulfate, sulfite and sulfide, respectively, at the $72^{\text {th }}$ hour was measured.
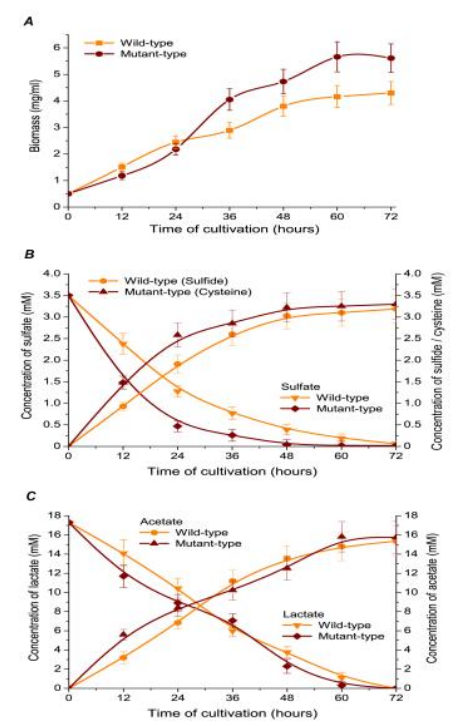

Fig. 1. Physiological properties of the Desulfovibrio piger Vib-7 wildand mutant-type $(\mathrm{M} \pm \mathrm{m}, \mathrm{n}=5): A$ - bacterial growth in Kravtsov-Sorokin's liquid medium; $B$ - consumption of sulfate as an electron acceptor accumulation of sulfide and cysteine; $C$ - consumption of lactate as an electron donor and accumulation of acetate.

In literature, there are some data on the enzyme activity inhibition by product (Fimmel and Loughlin, 1977; Wiater and Hulanicka, 1979; Boronat et al., 1984). Therefore, the inhibition of the enzyme activity of $O$-acetylserine (thiol) lyase under the effect of cysteine during bacterial growth in the cultivation medium was studied (Fig. 2C). The level of the enzyme inhibition depended on time of bacterial growth and, accordingly, additional accumulation of cysteine in the cultivation medium. As result of the enzyme activity inhibition, sulfide accumulation in the medium was observed. The highest level of sulfide 


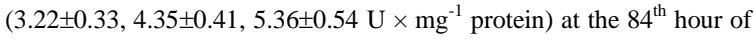
cultivation was measured in medium with cysteine+sulfate, cysteine+sulfite and cysteine+sulfide, respectively. Under these conditions, the activity of $O$-acetylserine(thiol)lyase was the lowest compared to the $36^{\text {th }}$ hour of cultivation and the enzyme was almost completely inhibited.

Cysteine is an essential amino acid, unique in its ability to form disulfide linkages and also critical in the catalytic centers of many proteins (Droux, 2004; Rausch and Wachter, 2005). In bacteria, cysteine is synthesized from serine by incorporation of sulfide or thiosulfate. In the first step, $O$-acetylserine is formed by serine transacetylase, the $c y s E$ gene product (Boronat et al., 1984). Cysteine is then produced in a reaction catalyzed by the enzyme $O$-acetylserine (thiol)-lyase-A or $O$-acetylserine(thiol)-lyase-B, encoded by the cys $K$ and cys $M$ genes, respectively. Cysteine biosynthesis in plants is quite similar, although the respective genes have only recently been cloned and only one isozyme of $O$-acetylserine (thiol)-lyase has so far been identified. In animals, the transsulfuration pathway derives the sulfur group of cysteine from methionine and the carbon skeleton and amino group from serine (Kitabatake et al., 2000).
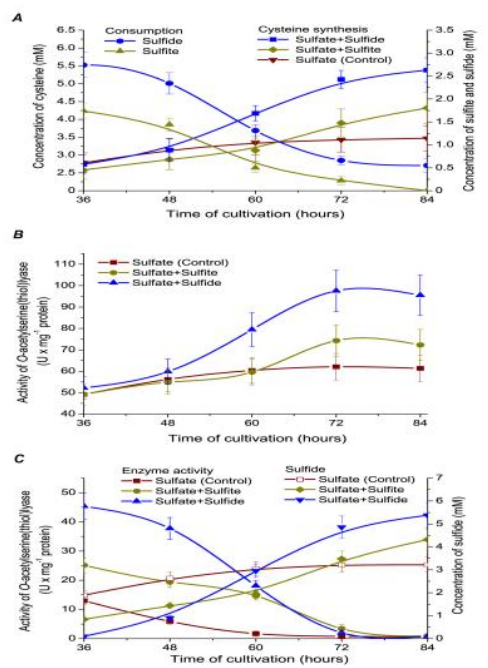

Fig. 2. Biochemical properties of the Desulfovibrio piger Vib-7 wildand mutant-type $(\mathrm{M} \pm \mathrm{m}, \mathrm{n}=5): A$ - cysteine accumulation and consumption of sulfite and sulfide; $B$ - enzyme activity of $O$-acetylserine(thiol)lyase under the effect of sulfate, sulfite and sulfide during bacterial growth in the cultivation medium; $C-$ inhibition of the enzyme activity of $O$ acetylserine(thiol)lyase and accumulation of sulfide under the effect of cysteine $(3 \mathrm{mM})$ during bacterial growth in the cultivation medium.

The pathway of cysteine biosynthesis in archaea Methanosarcina barkeri was demonstrated by Kitabatake et al. (2000). Complementation of a cysteine auxotrophic Escherichia coli strain NK3 led to the isolation of the $M$. barkeri $c y s K$ gene, which displays great similarity to bacterial cys $K$ genes. Adjacent to $c y s K$ is anopen reading frame orthologous to bacterial cysE (serine transacetylase) genes. Analysis of recent genome data revealed the presence of bacteria-like cysM genes in Pyrococcus spp., Sulfolobus solfataricus, and Thermoplasma acidophilum. However, no orthologs for these genes can be found in Methanococcus jannaschii, Methanobacterium thermoautotro-phicum, and Archaeoglobus fulgidus, implying the existence of unrecognizable genes for the same function or a different cysteine biosynthesis pathway (Kitabatake et al., 2000).

Boronat et al., (1984) have reported that the plasmid pAB65, derived from a specialized transducing phage carrying DNA from about $52 \mathrm{~min}$ on the $E$. coli genome, coded for two polypeptides of $M_{\mathrm{r}}$ approx. 34000 . The expression of one was regulated by cystine and the $c y s B$ gene product and the other by the cys $B$ gene product only. One of these polypeptides was a subunit of $O$-acetylserine(thiol)-lyase. The pattern of peptide synthesis directed by plasmids carrying smaller DNA fragments indicated that the gene for $O$-acetylserine(thiol)lyase was transcribed clockwise. The spectrum, amino acid composition and subunit number of the enzyme were determined. The enzyme appears homologous with the Salmonella typhimurium cysK gene product (Boronat et al., 1984).

Yamamoto et al. (2011) have showed that the expression of cysK in $E$. coli was under the control of $C y s B$, a $L y s R$ family transcription facto rand theexpression of cys $K$ was regulated by several genetic and environmental factors in addition to $C y s B$ : two genetic factors, $O m p R$ and $C y s E$, and lithium. Based on the findings, authors constructed the high-level expression system of cysK (Yamamoto et al., 2011). Mutants of $C y s K$, deficient in $O$-acetylserine sulphydrylase A [Oacetyl-L-serine acetate-lyase (adding hydrogen-sulphide)], were isolated as strains resistant to selenite or giving a black colour reaction on bismuth citrate indicator medium by Fimmel and Loughlin (1977). Authors have demonstrated that all strains were resistant to the inhibitor 1,2,4-triazole. Strains containing both a cysE mutation and a cysK mutation lacked the constitutive levels of NADPH-sulfite reductase showing that these levels were due to the in vivo concentration of the inducer, $O$-acetylserine. The $c y s K$ locus was found to be $81 \%$ cotransducible with the ptsI gene (Fimmel and Loughlin, 1977). Triazole and azaserine resistant $C y s K$ mutants of E. coli K12 were also studied by Wiater and Hulanicka in 1979.

The cysteine role as an amino acid in proteins, cysteine functions as a precursor for a huge number of essential biomolecules, such as vitamins and cofactors (Droux, 2004; Wirtz et al., 2004), antioxidants like glutathione, which is regarded as the major determinant of cellular redox homeostasis, and many defense compounds is very important (Rausch and Wachter, 2005). All of these biomolecules contain sulfur moieties that act as functional groups and are derived from cysteine. The biosynthesis of cysteine is accomplished through two sequential reactions catalyzed by the enzymes serine acetyltransferase, which synthesizes the intermediary product $O$-acetylserine, and $\mathrm{O}$ acetylserine(thiol)lyase, which combines sulfide with $O$-acetylserine to produce cysteine. Together, these two enzymes form the heterooligomeric cysteine synthase complex, which was first described in bacteria (Droux et al., 1998).

In summarizing all results of our studies, we can conclude that the $c y s K$ gene from $E$. coli genome was cloned and transferred in the intestinal sulfate-reducing bacterium $D$. piger Vib-7 wild-type. The expression of the cysK gene by the formation of the final reaction product (cysteine) and the activity of O-acetylserine(thiol)lyase enzyme was studied. Schematic of sulfate reduction to cysteine in $D$. piger Vib-7 mutant-type was demonstrated:

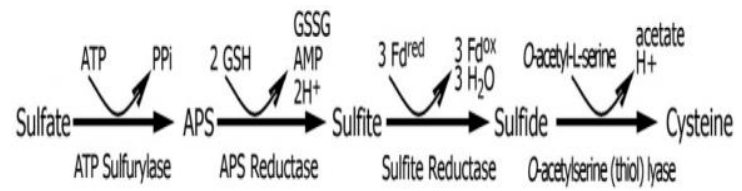

ATP sufurylase produces adenosine-5'-phosphosulfate (APS); sulfite is then formed from APS by glutathione-dependent APS reductase; sulfide is catalyzed from the generated sulfite by ferredoxin-dependent sulfite reductase; $O$-acetylserine(thiol)-lyase catalyzes the reaction of sulfide and O-acetyl-L-serine to synthesize cysteine (Brychkova et al., 2012).

\section{Conclusion}

The $c y s K$ gene mutant-type of sulfate-reducing bacterium $D$. piger Vib-7 was genetically constructed. This mutant-type accumulated biomass by $36 \%$ higher than the wild-type. That was consistent to the studies of dynamics of sulfate and lactate consumption as well as 
accumulation of sulfide/cysteine and acetate. The D. piger Vib-7 mutant-type also consumed these substrates much faster than the wildtype. The expression of the cys $K$ gene in the mutant-type was studied by the formation of the final reaction product (cysteine) and the activity of $O$-acetylserine(thiol)lyase enzyme.

Cysteine level was directly proportional to consumption of sulfate in the mutant-type and accumulation of sulfide in the wild-type. The $D$. piger Vib-7 mutant-type completely used sulfate the $48^{\text {th }}$ hour of cultivation, thereafter additional sulfite and sulfide doses from the medium were also consumed and converted to cysteine. However, additional cysteine dose $(3 \mathrm{mM})$ caused the inhibition of $O$ acetylserine(thiol)lyase activity and accumulation of sulfide that was typical for wild-type of the sulfate-reducing bacteria.

According to all obtained results, the studies of the dissimilatory sulfate reduction in the D. piger Vib-7 mutant-type, its consumption of substrates, utilization of toxic sulfide and production of cysteine in detail can be perspective for clarification of their etiological role in the development of the humans and animals bowel diseases. The obtained genetically constructed mutant strain bacterium D. piger Vib-7 for therapeutic strategy could be applied as a probiotic substance for subjects with inflammatory bowel disease and ulcerative colitis. This strain could compete with other intestinal sulfate-reducing bacteria, actively growth consuming sulfate and lactate much faster, and converting the toxic sulfide to untoxic cysteine in the gut. At present, the only possibility to hand is to try to manipulate the intestinal microflora by adding potential protective bacteria such as probiotics. Preliminary clinical studies have confirmed that this approach might be extremely useful. However, much more work is necessary to understand why probiotics are able to compete with aggressive bacteria and how the communication between microflora and the immune system in healthy and ulcerative colitis patients works. The D. piger Vib-7 mutant-type is valuable and indispensable tools that provide a wide range of options for investigating involvement of various factors into the pathogenesis of inflammatory bowel disease and ulcerative colitis to evaluate different therapeutic options.

\section{Acknowledgements}

This study was supported by University of Veterinary and Pharmaceutical Sciences Brno (project OPVK „Pharmacotoxicological evaluation of newly synthesized (isolated) compounds as an integration tool for pre-clinical disciplines at VFU Brno" CZ.1.07/2.3.00/30.0053).

\section{References}

Bailey, N.T.J. Statistical Methods in Biology. 1995. Cambridge University Press. 3rd edition, 252 p. http://dx.doi.org/ 10.1017/CBO9781139170840

Barton, L.L., Hamilton, W.A. 2010. Sulphate-Reducing Bacteria. Environmental and Engineered Systems. Cambridge: Cambridge University Pres. 553 p. http://dx.doi.org/10.1017/ CBO9780511541490

Becker, M.A., Kredich, N.M., Tomkins, G.M. 1969. The purification and characterization of O-acetylserine sulfhydrylase-A from Salmonella typhimurium. J. Biol Chem., 244: 2418-2427.

Boronat, A., Britton, P., Jones-Mortimer, M.C., Kornberg, H.L., Lee, L.G., Murfitt, D., Parra, F. 1984. Location on the Escherichia coli genome of a gene specifying O-acetylserine(thiol)lyase. J. Gen. Microbiol., 130: 673-685.

Brychkova, G., Yarmolinsky, D., Sagi, M. 2012. Kinetic assays for determining in vitro APS reductase activity in plants without the use of radioactive substances. Plant Cell Physiol., 53(9): 16481658.

Chapman, M.A.S., Grahn, M.F., Boyle, M.A. 1994. Butyrate oxidation is impaired in the colonic mucosa of sufferers of quiescent ulcerative colitis. Gut, 35: 73-76.

Cline, J.D. 1969. Spectrophotometric determination of hydrogen sulfide in natural water. Limnol Oceangr, 14: 454-458.

Cummings, J.H., Macfarlane, G.T., Macfarlane, S. 2003. Intestinal Bacteria and Ulcerative Colitis. Curr. Issues Intest. Microbiol, 4: 9-20

Droux, M., Ruffet, M.-L., Douce, R., Job, D. 1998. Interactions between serine acetyltransferase and $\mathrm{O}$-acetylserine(thiol) lyase in higher plants. Structural and kinetic properties of the free and bound enzymes. European Journal of Biochemistry, 255: 235-245.

Droux, M. 2004. Sulfur assimilation and the role of sulfur in plant metabolism: a survey. Photosynthesis Research, 79: 331-348.

Fimmel, A.L., Loughlin, R.E. 1977. Isolation and characterization of cysK mutants of Escherichia coli K12. J. Gen Microbiol., 103(1): $37-43$.

Gaitonde, M.K. 1967. A spectrophotometric method for the direct determination of cysteine in the presence of other naturally occurring amino acids. Biochem J., 104: 627-633.

Gibson, G.R., Cummings, J.H., Macfarlane, G.T. 1991.Growth and activities of sulphate-reducing bacteria in gut contents of health subjects and patients with ulcerative colitis. FEMS Microbiol. Ecol, 86: 103-112. http://dx.doi.org/ 10.1111/j.15746968.1991.tb04799.x

Jones-Mortimer, M.C. 1968): Positive control of sulphate reduction in Escherichia coli. Isolation, characterization and mapping of cysteineless mutants of E. coli K12. Biochem. J., 110(3): 589-595.

Kitabatake, M., So, M.W., Tumbula, D.L., Soll, D. 2000. Cysteine biosynthesis pathway in the archaeon Methanosarcina barkeri encoded by acquired bacterial genes? J. Bacteriol., 182(1): 143145 .

Kolmert, A., Wikstrom, P., Hallberg, K.B. 2000. A fast and simple turbidimetric method for the determination of sulfate in sulfatereducing bacterial cultures. J. Microbiol. Methods, 41: 179-184.

Kushkevych, I.V. 2012a. Sulfate-reducing bacteria of the human intestine. I. Dissimilatory sulfate reduction. Studia Biologica, 2012; 6(1): 149-180. http://bioweb.lnu.edu.ua /studia/?p=article \&year=2012\&tom $=6 \&$ nomer $=1 \&$ id $=175$

Kushkevych, I.V. 2012b. Sulfate-reducing bacteria of the human intestine. II. The role in the diseases development. Studia Biologica, 6(2): 221-250. http://bioweb.lnu.edu.ua/ studia/?p=article $\&$ year=2012\&tom $=6 \&$ nomer $=2 \& i d=199$

Kushkevych, I.V. 2013. Identification of sulfate-reducing bacteria strains of human large intestine. Studia Biologica, 7(3): 115-124. http://bioweb.lnu.edu.ua/studia/?p=article \&year $=2013 \&$ tom $=7 \&$ nomer $=3 \&$ id $=277$

Kushkevych, I.V., Bartoš, M., Bartošová, L. 2014. Sequence analysis of the 16S rRNA gene of sulfate-reducing bacteria isolated from human intestine. Int. J. Curr. Microbiol. Appl. Sci., 3(2): 239$248 . \quad$ http://www.ijcmas.com/vol-32/Ivan\%20Kushkevych,\%20et\%20al.pdf

Levine, J., Ellis, C.J., Furne, J.K., Springfield, J., Levitt, M.D. 1998. Fecal Hydrogen Sulfide Production in Ulcerative Colitis. The American J. Gastroenterol., 93(1): 83-87.

Loubinoux, J., Bronowicji, J.-P., Pereira, I.A. et al. 2002. Sulphatereducing bacteria in human feces and their association with inflammatory diseases. FEMS Microbiol Ecol., 40: 107-112. 
Loubinoux, J., Mory, F., Pereira, I.A. et al. 2000. Bacteremia caused by a strain of Desulfovibrio related to the provisionally named Desulfovibrio fairfieldensis. J Clin Microbiol., 38: 931-934.

Low, D., Nguyen, D.D., Mizoguchi, E. 2013. Animal models of ulcerative colitis and their application in drug research. Drug Design, Development and Therapy, 7: 1341-1357.

Lowry, O.H., Rosebrough, N.J., Farr, A.L., Randall, R.J. 1951. Protein determination with the Folin phenol reagent. J. Biol. Chem., 193: 265-275.

Ohge, H., Furne, J.K., Springfield, J., Sueda, T., Madoff, R.D., Levitt, M.D. 2003. The effect of antibiotics and bismuth on fecal hydrogen sulfide and sulfate-reducing bacteria in the rat. FEMS Microbiol Lett, 228: 137-142.

Pitcher, M.C., Cummings, J.H. 1996. Hydrogen sulphide: a bacterial toxin in ulcerative colitis? Gut, 39: 1-4.

Rausch, T., Wachter, A. 2005. Sulfur metabolism: a versatile platform for launching defence operations. Trends Plant Sci, 10(10): 503509 .

Roediger, W.E.W., Duncan A., Kapaniris, O. 1993a. Sulphide impairment of substrate oxidation in rat colonocytes: A biochemical basis for ulcerative colitis? Clin Sci., 85: 623-627.

Roediger, W.E.W., Duncan, A., Kapaniris, O., Millard, S. 1993b. Reducing sulfur compounds of colon impair colonocyte nutrition: implications for ulcerative colitis. Gastroenterology. 104, 802809.

Roediger, W.E.W., Nance, S. 1986. Metabolic induction of experimental ulcerative colitis by inhibition of fatty acid oxidation. Br J Exp Pathol., 67: 773-782.

Rowan, F.E., Docherty, N.G., Coffey, J.C. et al. 2009. Sulphatereducing bacteria and hydrogen sulphide in the aetiology of ulcerative colitis. British J Surgery, 96: 151-158.

Sutton, S. 2011. Measurement of Microbial Cells by Optical Density. J. Valid Tech., 17(1): 46-49.

Wiater, A., Hulanicka, D. 1979. Properties of cysK mutants of Escherichia coli K12. Acta Biochim Pol., 26: 21-28.

Wirtz, M., Droux, M., Hell, R. 2004. O-acetylserine(thiol)lyase: an enigmatic enzyme of plant cysteine biosynthesis revisited in Arabidopsis thaliana. J. Exp. Bot., 55(404): 1785-1798.

Yamamoto, K., Oshima, T., Nonaka, G., Ito, H., Ishihama, A. 2011. Induction of the Escherichia coli cysK gene by genetic and environmental factors. FEMS Microbiology Letters, 323(1): 8895. 